\title{
CONCEPT OF A DOCUMENT AND DOCUMENTS' TRANSFORMATION AS TECHNOLOGY CHANGES
}

\author{
Danutè Kontrimavičienè \\ Lithuanian State Modern Archives (Vilnius, Lithuania)
}

\section{INTRODUCTION}

Scientific discussions about concept of a document and its distinction from a medium began at the end of the 20th century, when drawing-up of documents in a digital format started and a need to define integrity, permanence and authenticity of such documents (which are considered indivisible and necessary properties of a document in time) arose. Analogue documents (written, photo or audio \& video documents) are inseparable from a medium, therefore it is always possible to verify their authenticity and uniqueness using technical means. But how to handle a document, which was created using the means of information technologies and is not strictly attached to a physical medium? Does such a document become unreliable, not authentic and not unique? Information technologies enable creation of digital documents, which it is easy to transmit or to duplicate, but it is hard to ensure their authenticity and it might be difficult to review and to use them in the future.

In order to manage the digital information with high quality, we have to give up a common point of view and belief that a document is unchangeable and strictly attached to a physical medium. Creation of electronic documents and their management during the last century paved conditions for switching to the information management. Until 2020, even when speaking about the electronic documents we attached ourselves to a concept of a paper document: text of a document and the electronic signature which ensures its authenticity. This point of view is identical as in case of the paper documents. Nevertheless, at the same time information systems and state registers were created in fact, on which not only the documents, but also information was managed. Hence, today I would like to start speaking in a language which is the closest to a document, distinguishing it from an image of a paper document, - that is about its concept.

\section{DOCUMENTS' TRANSFORMATION}

In Lithuania a prevailing concept of a document has been existing for 16 years, according to which a document - information fixed during a process of activity, no matter its way of presentation, form and medium. Document means information recorded in the course of activities of a legal or a natural person, regardless of its mode, form and medium [1]. In 2016 this concept was amended, according to which it is information recorded in the course of activities of a legal person established in the Republic of Lithuania or in a foreign country, other organization or its branch (hereafter - legal person) or a natural person. Speaking about a concept of an official document, it is narrowed, because it is a drawn-up, approved or received document by an authorized representative of a state or a municipal institution, office or enterprise, and registered. "Official document" means a document created, approved or received by a state or a municipal institution, agency or enterprise or a person authorised by the state, in conduct of the powers established by regulations. Such document shall be entered in the register [2]. It should be emphasized, that the key requirement - registration of a document. Also, it should be noted, that a contextual information is clearly defined, which is understood as information about structure, contents and context of a document, comprising necessary and sufficient conditions for authenticity and accessibility of a document. "Contextual information" means information about the structure, contents and context of a document, providing necessary and adequate conditions to ensure the authenticity and accessibility of a document [3]. So, all conditions for working with 
various forms of documents were created already in 2005 , but it took some time to change the usual forms of paper documents at institutions.

In order to encourage institutions to start working with the electronic documents, in 2010 definition of an electronic document was legitimized. "Electronic document" means a document of a legal or a natural person, which is created, approved or received by information technology means in accordance with the procedure laid down by regulations and is signed with a legally binding electronic signature [4]. Thus, this concept included all drawn-up electronic documents and signed by an electronic signature, in the manner prescribed by law. On July 23, 2014 European Parliament and Council Regulation (EU) No. 910/2014 on electronic identification and trust services for electronic transactions in the internal market and repealing Directive 1999/93/EC was adopted, and above-mentioned concept had to be précised, because in the Regulation it was defined that an „electronic document" means any content stored in the electronic form, in particular text or sound, visual or audiovisual recording [5]. Therefore, since July 1, 2016 the concept and the definition of an electronic document have changed in Lithuania - official electronic document at present is perceived as an electronic document drawn-up, approved or received by a state or a municipal institution, office or company, a state authorised person using the means of information technologies, signed by an electronic signature and registered in the manner established by a Chief Archivist of Lithuania [6]. It should be noted, that the original concept was narrowed in the national legislation, because it is stated that it is a document created by state institutions in the manner established by a Chief Archivist of Lithuania.

Despite the fact that a document has been understood as information no matter its form and medium since long time ago, as established by the Law on Documents and Archives, it took 10 years to start a circulation of official electronic documents. Also, during this period at the courts of law functioning of a substitute of paper minutes of court sittings began: minutes - audio record, created not in analogue, but in a digital form, which completely changed paper minutes in a court case.

Year 2020 can be considered as a new step in working with information, but not with documents. New versions of Rules of Drawing-up of Documents, Rules of Management \& Registering of Documents, and Rules of Preservation of Documents came into force. Separate rules on management of the electronic documents were renounced, a part of the rules related to drawing-up of the electronic documents were transferred to the Rules of Drawing-up of Documents; management and registering of the electronic documents were transferred to the Rules of Management \& Registering of Documents, and the requirements for preservation of the electronic documents were set out in the Rules of Preservation of Documents [7]. Also, a new concept "digitally born document" was formulated - information fixed in a digital format, managed by the means of information technologies [8].

In the Rules of Drawing-up of Documents a concept of medium of a document was separated. Thus, a medium can be of two types: physical and digital. A physical type is set when documents are preserved on physical media, while a digital medium is set in cases when documents are preserved on information systems, i.e., created in a digital format.

So, when we start speaking about information, which fixes, legitimizes or proves a particular legal fact, approves a conducted action, we can decide regarding a choice of the most convenient method for fixing this information. We have to consider, what will be more efficient for fixation of information - a paper document, an audio record, a video and an audio record, can a record be created. In order to eliminate possible problems with the transmission of files, the Rules of Drawing-up of Documents foresees that a medium and MIME type tag can be specified on the information system. MIME ${ }^{1}$ type tag can be specified on metadata of a digital origin and on digitised documents (e.g., application/vnd.lt.archyvai.adoc-2008, application/pdf). It should

\footnotetext{
${ }^{1}$ MIME (Multipurpose Internet Mail Extensions) is an Internet standard that extends the format of email messages to support text in character sets other than ASCII, as well as attachments of audio, video, images, and application programs.
} 
be taken into consideration that on the metadata of records MIME type tag of the record is specified (and not MIME type tags of textual, visual and audio files comprising the record).

As it was already mentioned, conditions for appearance of documents in other formats are favourable since 2005, however only in rare cases it was relinquished to draw-up written documents (paper or electronic). Thus, we can assert that the establishment of integrity of documents, as comprised of three elements in the Rules of Drawing-up of Documents, will encourage assessing the procedures of drawing-up of documents once again. Since January 1, 2020 structure of a document is enforced, which is comprised of three main elements: text or image and (or) sound, metadata, data confirming authenticity and integrity. All structural elements of a document are mandatory and are fixed in a document depending on a chosen or set out form of a document.

While discussing the established requirements for the first element of a document - text or image and(or) sound, first of all it should be noted that this element can be named as an informational element, because it contains information comprising a document [9]. Text, image and (or) sound of a document is a mandatory part of a document, in which the main information of a document and information on its enclosures is provided - in this part of a document additional information to the main text or image and (or) sound can be presented (in this case an enclosure should have its name and can be amended with the enclosure's tag), or a document the drawing-up procedure of which is finished (e.g.: document drawn-up by an institution, received, copy of a document, transcript or extract). So, speaking about the written documents (paper and electronic), text of a document is perceived as it is defined in a standard LST ISO 5127:2019, i.e., "data", which are used in order to transmit a certain "value" via "language" and interpretation which is essentially depending upon the reader's "knowledge" of "natural language"or "artificial language". Also, this standard provides a note, that "text" can be expressed via „oral communication” or fixed in "writing”, thus comprising a "document". While a video and (or) audio document is perceived as a fixed picture (moving or static) and (or) sound, no matter its physical basis of fixation and recording (fixation) method (e.g.: movie, audio record, photo-document).

Speaking about the second element of a document - metadata, they are understood as the data about the document, its management and use. It also should be noted that metadata are separated into the main and the additional. The main metadata of a document are the following: name of author (creator) of a document; title of a document; date of a document; registration number of a document; recipient (if a document is sent); data of author of a document (if a document is sent). A written document may have additional metadata as well, such as: a special tag; enclosure tag; data of receipt of a document; assignment (resolution or another); reference of a received document; tag of coordination; tag of acknowledgement; tag of approval; tag of authenticity; reference of author of a document. It should be taken into account that upon need documents of other forms may have additional metadata, which in many cases will be fixed by the means of information technologies.

While discussing the main metadata, it should be mentioned that the author (creator) of a document is understood as an institution, a division of its administration, a collegial unit, head of institution or other authorized person to draw-up the documents. Title of a document is comprised of name of a document's sort (order, protocol, deed, etc.) and a header, briefly describing the essence of text of a document. As an exception, in the sent documents only the header can be indicated, without indicating the name of a document's sort. Date of a document is considered its registration date. Date of a document is indicated in groups of the Arabic digits (2019-06-05) or in a mixed way (2019 March 5). Registration number of a document - a unique number of a document, assigned by head of an institution in a prescribed manner. Registration number of a document is comprised of a set of numbers and (or) letters, confirming the fact of creation or receipt of a document, after the date abbreviation "No." of a word "number" is indicated. Besides, upon a need the registration number of a document can be appended with punctuation signs - period, hyphen, parentheses, slash, etc. Recipient is specified in a document, 
if a document is sent or when an institution, a division of its administration or a person, to whom the document is intended, needs to be indicated. Data of the author of a document - in the documents for sending information foreseen in the Article 2.44 of the Civil Code of the Republic of Lithuania is specified (business name of a legal person; juridical form of a legal person; head office of a legal person; code of a legal person; register which stores and preserves the data on the given legal person [10], other necessary information (e.g., National electronic parcels delivery information system electronic delivery box). When the author of a document is a territorial unit or branch (representation) of an institution, in addition the contact data of a territorial unit or branch (representation) may be indicated.

While analysing the requirements for the data of the third element of a document authenticity and (or) confirmation of integrity, it is important to note that a signature on a document remains the only method assuring authenticity and integrity of a document. The Rules of Drawing-up of Documents distinguishes four ways of confirming authenticity and (or) integrity of a document. The first method - signature, put on paper documents, in the contents of a document, indicating the signatory's (confirming) person's position, name and surname. The second method - electronic signature, indicating the person's, who created the electronic signature, position, name and surname. Besides, if this information is not indicated in the certificate of an electronic signature, it must be provided in the metadata. It should be taken into consideration, that the electronic signature is understood as the data in electronic form which is attached to or logically associated with other data in the electronic form and which is used by the signatory to sign. It can be a qualified electronic signature, advanced electronic signature or an electronic signature which does not meet the requirements for the qualified electronic signature provided for in Regulation (EU) No 910/2014 shall have the equivalent legal effect of a handwritten signature, where the users of that electronic signature agree in writing in advance and where it is possible to store that agreement on a durable medium [11]. Also, it is necessary to pay attention, that if it is mandatory to use not only a signature but also a stamp on a document form, a qualified electronic signature of a representative of a legal person shall have the equivalent legal effect of a handwritten signature of a legal person authenticated by the stamp of a legal person, where an obligation to have the stamp is established in the legal person's instruments of its establishment or laws [12]. The third method - an electronic seal, which is understood as the data in electronic form, attached to or logically associated with other data in the electronic form to ensure the latter's origin and integrity. When using an electronic seal, name of the author (legal person) of an electronic seal is specified. If this information is not indicated on the certificate of an electronic seal, it must be provided in the metadata. An electronic seal, as an electronic signature, can be qualified ${ }^{2}$ or not. The fourth method comprises other technologies used for assuring the integrity of contents of a document (electronic time stamps, etc.).

If signing of a document has always been the action taken for granted, there is one important change in the documents' management since 2020: now it is not necessary to sign all documents, in order to assure their authenticity and integrity. Requirement for signing the documents, which has been one of the mandatory requisites according to the Rules of Drawingup of Documents until 2020, now is abolished and from now particular legal acts establish whether a document must be signed (but this provision was abolished in the requirements for drawing-up the documents). Thus, at present the following types of documents must be signed: legal acts by a collegial unit, single-person subject or several subjects, issued according to competence of these institutions or subjects; agreements or contracts (except agreements or contracts which may be not signed according to the manner established by laws); individual administrative acts; documents confirming legal facts sent to foreign recipients; representation documents of an institution (authorisations, claims, conclusions, etc.) and other documents established in the legal acts. Besides, speaking about the electronic documents, it is indicated that

\footnotetext{
2 "Qualified electronic seal" means an advanced electronic seal, which is created by a qualified electronic seal creation device, and that is based on a qualified certificate for electronic seal.
} 
a qualified electronic signature (for signing, approval or coordination, when a drawn-up document is coordinated among different institutions) and a qualified time stamp are used for signing and (or) approval and coordination of official electronic documents, if it is not provided otherwise by the legal acts.

Concerning the documents drawn-up by an institution and not transferred to other legal persons, for confirming their authenticity and integrity one of the above-mentioned four methods can be chosen. This concerns official notices or other documents (requests, proposals, applications, deeds, etc.), by which procedures related to the execution of functions assigned to an institution by the legal acts are initiated; permits, consents and other documents (certificates, estimates, etc.), by which a legal fact or execution of a requested service is confirmed (except individual administrative acts); registers, summaries or other documents (lists, etc.), by which the results of executed technical operations are fixed. Moreover, it is necessary to draw attention that the Rules of Drawing-up of Documents grant right to choose a decision regarding the method for confirming of authenticity and (or) integrity of documents. On the other hand, it is clearly stated that such decisions may be taken only upon assessment of liabilities of an institution concerning the transfer of permanent digitised, digital origin or permanent electronic documents to the state archives and the technical means for preservation and (or) transfer of documents.

In regard to the fixation of elements in various types of documents, it should be noted that in a paper document all structural elements are fixed in the contents of a document ${ }^{3}$. In case of an electronic document there is a choice, when text is fixed in the contents, and other structural elements may be fixed in the contents and information systems or only information systems or use of other informational and communicational technologies. In a visual and (or) audio document picture and (or) sound is fixed, and other structural elements are fixed following the same principle, as in the case of electronic documents. Visual and (or) audio documents, which contents is fixed by creating an appropriate record, are drawn-up upon assessment of technical infrastructure for their creation, authenticity, reliability, integrity and suitability for use during all their preservation period. In order to prevent possible issues while drawing-up visual and (or) audio documents, the Rules of Drawing-up of Documents set out minimal technical requirements for the drawn-up visual and (or) audio documents, which are not objects of the copyright (legal acts, official administrative, legal or normative documents: decisions, judgments, regulations, norms, territories' planning and other official documents, meeting records, etc.): a record must be uninterrupted, except those cases when creation of a document (meeting, etc.) proceeds with breaks. If a record was interrupted due to technical reasons, it is necessary to specify the reasons of such event by drawing-up another document (certificate, official notice) or in another way. When drawing-up a visual and (or) an audio document, metadata can be amended with other contextual information as well (place, time of event (meeting, etc.), related decisions, duration etc.) [13]. The Rules of Management \& Registering of Documents establish the formats of such documents. Thus, no matter the preservation term of a document - permanent, long-term or short-term, visual and (or) audio documents can be drawn-up. Concerning the documents of this form, visual and (or) audio documents as operational documents, and visual and (or) audio documents as the objects of copyright and related rights should be distinguished. The difference is primarily in the process of their creation (drawing-up), and it is defined in the Rules of Drawing-up of Documents. A document is considered an operational document if it is a visual and (or) an audio record, a photography, in which an event is fixed which is not an object of the copyright and related rights. However, if photos are taken at events while publicizing an institution's activity, objects of the copyright and related rights are created, and they must be drawn-up in a manner not violating the Law on the Copyright and Related Rights of the Republic of Lithuania [14].

\footnotetext{
${ }^{3}$ Contents of a document - all information fixed in a document
} 
In 2020 a new sort of documents - "record" was introduced. The term of a "record" is understood as it is defined in the standard LST ISO 5127:2019. Record - document(s) containing recorded information created, received and maintained as evidence and as an asset by an organization or person, in pursuit of legal obligations or in the transaction of business. Records are created upon assessment of available software, which assure authenticity, reliability, integrity, suitability for use during all preservation period and protection against an alteration of their contents or destruction of the created records. A record is created and saved in the information system in such a way, that all data and (or) documents of a record are logically related. Besides, in the course of any review its fixed rendering via the means of information technologies must be assured. Several versions of a record can be created, but in this case previous versions of the key structural elements, specified in the Point 6 of the Rules, of a record must be saved, and a possibility to take them over assured. A record may be sent and can have other related documents. In the records, structural elements of a document are fixed on the related structural fields within a used information system. Also, a record must have the established key metadata of a document, although its rendering form can be set out in other legal acts.

Seeking to switch to the documents of only the digital origin, since January 1, 2020 an amendment to the Law on Documents and Archives has taken force. According to the provisions of Article 12 Paragraph 3, state and municipal institutions, agencies and enterprises, persons authorised by the state, non-governmental organisations, private legal persons can save the paper operational documents, except the documents for a permanent preservation, in the electronic from without saving a paper document, if a certainty of a digital picture of the paper document is assured. Manner (procedures) of selection of paper documents and their preservation in the electronic form is set out by the Chief Archivist of Lithuania. Please note that this provision is applicable to the documents accumulated at institutions prior adoption of the law. It is also worth noting, that this provision clearly states that the paper documents for a permanent preservation can be digitised only for the operational needs, but they cannot be destroyed - the state archives accept documents drawn-up in their original form.

Speaking about the digitisation of short-term documents, it should be noted that one of the last interpretations by the State Tax Inspectorate was based on the amendment to the Law on Documents and Archives and its by-law - Description of the Selection of Paper Documents and their Preservation in the Electronic Form [15], concerning the digitisation of financial activity paper documents and their preservation in the electronic form. Following the interpretation, this method of the documents' management is considered legal and not violating the provisions of the Law on the Bookkeeping, and appropriate for proving the financial operations. This will enable many state institutions and private enterprises to switch to management of documents only of the digital origin.

What requirements are set out for a digitisation of the paper documents and their preservation in the electronic form? The Description establishes the requirements for selection, digitisation, preservation in the electronic form and destruction of short-term and (or) long-term paper operational documents. At first, in order to save the paper documents in the electronic form, an institution's, organisation's or enterprise's operations' accountability requirements (submission requirements for audit and supervising institutions' original paper documents, etc.) should be assessed; a need for proving of contractual obligations or execution of other lawful liabilities by authentic documents; possibilities to assure the certainty of a digital picture of a paper document in the manner set out in the Description; a ratio of foreseen costs and financial benefit (decrease of expenditures for preservation of documents and (or) their management services, or upkeep of premises for preservation of documents, expenditures saved for labour wages, etc.); time, human resources costs (digitisation of paper documents, description of digital pictures (if applicable) costs, maintenance of documents in the electronic form during the period of their preservation costs); created digital pictures of paper documents - documents in the electronic form - preservation, ensuring access to them during all preservation period established 
by the legal acts, implementation of the chosen technological solutions costs; other activity needs or possible costs (employees' training, changes in activity processes or procedures, etc.). When digitising the paper documents, it is recommended to use the following formats of digital contents and quality parameters: JPG or TIFF, PDF, not less than 300 dpi resolution and 24 bits colour depth. These requirements are applicable for uncompressed files.

Concerning the preservation of documents in the electronic form, two methods are set out. The first method is in a package of the official electronic document, complying with the requirements of the Electronic document signed by an electronic signature specification ADOC-V1.0, approved by the Order of September 7, 2009 No. V-60 "Concerning approval of the Electronic document signed by an electronic signature specification ADOC-V1.0" [16] by the Chief Archivist of Lithuania. The package is managed in the documents' management or other information system. In this case the integrity of documents is assured by a qualified electronic copy authenticity destination signature of the person who digitised a document or other responsible person. The second method - in the documents' management or other information system, by which means the metadata of file are managed, without creating a package of the official electronic document. In this case the integrity of documents in the electronic form is assured by the electronic signature of the person who digitised a document or other responsible person.

There is a period left to insure against possible disputes, during which the originals of paper documents must be saved and only afterwards destructed, i.e., 6 months following the end of all related procedures and tasks (actions). After this period and after completion of the aforementioned procedures, documents can be destroyed and in this case the act of destruction of documents is not drawn-up. Speaking about a further preservation of documents in the electronic form it is necessary to emphasize, that they are managed and preserved as the digitised or the official electronic documents, if a decision was taken to transfer a digital picture of the paper document to ADOC package. Therefore, the electronic form document is managed as an operational document in an institution, organisation or enterprise and it is possible to destroy it only upon expiration of a preservation term and conducting of a value appraisal. If a retention term of documents preserved in the electronic form has not been extended, they are included into the act of destruction of documents.

It is important to discuss one more aspect, that is - peculiarities of destruction of paper documents of those institutions which transfer the documents after 6 months following the completion of tasks. An institution informs the state archive in writing about a foreseen destruction of paper documents, and upon a need possibility to acknowledge with the documents scheduled for destruction is made. This way, assurance is made that important originals of (historic) documents are not destroyed.

\section{CONCLUSIONS}

Generalising the latest changes in the regulation of workflow, concept of a document and possible its forms, we can conclude that the goal is to simplify and facilitate work with documents from their creation until their transfer to preservation, also to ease the administrative requirements and resources needed for execution of the delegated functions. Legal regulation creates more possibilities for choosing different forms of document, thus transferring responsibility to the managers of institutions, so they make responsible decisions regarding creation and preservation of documents. While a workflow becomes more democratic, more responsibility lies with the drawn-up documents. No matter their form, we have to preserve the documents for future researchers and to transfer them to the state archives.

\section{REFERENCES}

[1] Law on Documents and Archives of the Republic of Lithuania. URL: https://eseimas.lrs.lt/portal/legalAct/lt/TAD/TAIS.426255?jfwid=-lrklxcxem.

[2] Law on Documents and Archives of the Republic of Lithuania. URL: https://eseimas.lrs.lt/portal/legalAct/lt/TAD/TAIS.426255?jfwid=-lrklxcxem. 
[3] Law on Documents and Archives of the Republic of Lithuania. URL: https://eseimas.lrs.lt/portal/legalAct/lt/TAD/TAIS.426255?jfwid=-lrklxcxem.

[4] Law on Documents and Archives of the Republic of Lithuania. URL: https://eseimas.lrs.lt/portal/legalAct/lt/TAD/TAIS.426255?jfwid=-lrklxcxem.

[5] Regulation (Eu) No 910/2014 Of the European Parliament and Of the Council of 23 July 2014 on electronic identification and trust services for electronic transactions in the internal market and repealing Directive 1999/93/EC. URL: $=$ CELEX:32014R0910\&from=LT\#d1e3055-73-1

[6] Law on Documents and Archives of the Republic of Lithuania. URL: https://www.etar.lt/portal/lt/legalAct/TAR.1FEF229DA7C6/asr.

[7] Dokumentu saugojimo taisyklès, Lietuvos vyriausiojo archyvaro $2011 \mathrm{~m}$. gruodžio 28 d. ịsakymu Nr. V-157 "Dèl Dokumentų saugojimo taisyklių patvirtinimo". URL: https://www.e-tar.lt/portal/lt/ legalAct/ TAR.2EBA39845DEE/asr.

[8] Dokumentu rengimo taisyklès, Lietuvos vyriausiojo archyvaro $2011 \mathrm{~m}$. liepos 4 d. isakymas Nr. V-117 "Dèl Dokumentu rengimo taisykliu patvirtinimo". URL: https://e-seimas.lrs.lt/portal/legalAct/lt/ TAD/TAIS.403753/asr.

[9] Dokumentų tvarkymo ir apskaitos taisyklès, Lietuvos vyriausiojo archyvaro $2011 \mathrm{~m}$. liepos 4 d. įsakymas Nr. V118, "Dèl Dokumentu tvarkymo ir apskaitos taisykliu patvirtinimo". URL: https://eseimas.lrs.1t/portal/legalAct/lt/TAD/TAIS.403754/asr.

[10] Civil Code of the Republic of Lithuania. URL: https://e-seimas.lrs.lt/portal/legalAct/lt/TAD/ TAIS.245495.

[11] Law of the Republic of Lithuania on Electronic Identification and Trust Services for Electronic Transactions. URL: https://e-seimas.lrs.lt/portal/legalAct/en/TAD/c5174772ecd011e89d4ad92e8434e309.

[12] Law of the Republic of Lithuania on Electronic Identification and Trust Services for Electronic Transactions. URL: https://e-seimas.lrs.lt/portal/legalAct/en/TAD/ c5174772ecd011e89d4ad92e8434e309.

[13] Dokumentų rengimo taisyklès, Lietuvos vyriausiojo archyvaro $2011 \mathrm{~m}$. liepos 4 d. ịsakymas Nr. V-117, "Dèl Dokumentų rengimo taisyklių patvirtinimo". URL: https://e-seimas.lrs.lt/portal/legalAct/ 1t/TAD/TAIS.403753/asr.

[14] Republic of Lithuania Law on Copyright and Related Rights. URL: https://e-seimas.lrs.lt/portal/ legalAct/lt/TAD/5f13b560b2b511e59010bea026bdb259?jfwid=9tq147ogj.

[15] Popierinių dokumentų atrankos ir išsaugojimo elektronine forma tvarkos aprašas, Lietuvos vyriausiojo archyvaro 2019 m. gruodžio 18 d. įsakymas Nr. V-73 „Dèl Popierinių dokumentų atrankos ir išsaugojimo elektronine forma tvarkos aprašo patvirtinimo“. $\quad$ URL: tar.lt/portal/lt/legalAct/c6518df021a711eabe008ea93139d588.

[16] Elektroniniu parašu pasirašyto elektroninio dokumento specifikacija ADOC-V1.0, Lietuvos vyriausiojo archyvaro $2009 \mathrm{~m}$. rugsèjo $7 \mathrm{~d}$. įsakymas Nr. V-60 „Dèl Elektroniniu parašu pasirašyto elektroninio dokumento specifikacijos ADOC-V1.0 pavirtinimo“. URL: https://e-seimas.lrs.lt/ portal/legalAct/lt/TAD/TAIS.352152/asr. 